\title{
Socialization of Increased Physical Fitness in the Covid Pandemic 19 Era
}

\author{
Arya T Candra1', Moh. Agung Setiabudi2, Mislan³, Deni Kurniawan Efendi ${ }^{4}$ \\ 1, 2, 3, 4, 5 PGRI Banyuwangi University \\ Email: ${ }^{1}$ aryacandra0189@gmail.com , 2agungsetiabudi.budi@gmail.com, ${ }^{3}$ mislanmpd680@gmail.com, \\ 4denikurniawanefendi3@gmail.com \\ d \\ https://doi.org/10.36526/gandrung.v1i2.936
}

\begin{abstract}
Physical condition is the most important indicator in the life of every community to maximize daily physical activity. Physical condition is very closely related to physical fitness. One of the most effective ways to maintain one's physical fitness is to do physical activity or exercise regularly and continue. Physical activity that is carried out routinely is of course also able to increase body immunity or a person's resistance to a virus or disease, one of which is covid 19. The target of this community service activity is the community in Sumberberas Village, RW 04. The socialization activity to increase physical fitness began on the 18th July 19 2020, 09.00-12.00 WIB and located in the Al Munir mosque in the village of Sumberberas. Material related to physical activities delivered and recommended are jogging, cycling and aerobics by taking into account health protocols and physical distancing. On the first day in the implementation of this socialization activity there were 30 participants who participated and on the second day there were additional members of 20 people. So that the total participants of this socialization activity were 50 people. Based on the evaluation results it can be concluded that the participation of the people who took part in this socialization activity was classified as good and the community was also very enthusiastic.
\end{abstract}

Keyword: Physical Condition, Physical Fitness, Body Immune

\section{Pendahuluan}

Kondisi fisik merupakan satu kesatuan utuh dan sistematis yang tidak dapat dipisahkan, baik cara peningkatannya maupunpemeliharaannya. Kondisi fisik merupakan indikator terpenting dalam kehidupan setiap masyarakat untuk memaksimalkan aktivitas fisik sehari-hari. Salah satu cara untuk meraih kondisi fisik yang maksimum yaitu dengan menjaga kebugaran jasmani. Adapun seseorang yang dikatakan bugar dalam kaitannya dengan aktivitas fisik diartikan sebagai orang yang mampu menjalankan kehidupan sehari-hari tanpa melampaui batas daya tahan dan memiliki tubuh yang sehat serta tidak beresiko mengalami penyakit yang disebabkan rendahnya tingkat kebugaran yang dikarenakan kurangnya aktivitas fisik.Salah satu cara paling efektif untuk menjaga kebugaran jasmani seseorang yaitu dengan melakukan aktivitas fisik atau berolahraga secara rutin dan continue.

Kebugaran jasmani yang berhubungan dengan kesehatan didefinisikan sebagai suatu kemampuan untuk melakukan aktivitas harian yang membutuhkan energi serta kualitas dan kapasitas yang diasosiasikan dengan rendahnya resiko munculnya penyakit yang berhubungan dengan kurangnya 
aktivitas fisik (Sukamti dkk, 2016). Aktivitas fisik yang dilakukan secara rutin tentunya juga mampu meningkatkan imunitas tubuh atau daya tahan seseorang terhadap suatu virus atau penyakit, salah satunya yaitu covid 19. Sistem imun (immune system) atau sistem kekebalan tubuh adalah kemampuan tubuh untuk melawan infeksi, meniadakan kerja toksin dan faktor virulen lainnya yang bersifat antigenik dan imunogenik (Siswanto dkk, 2013). Dengan tingginya sistem imunitas/daya tahan pada tubuh pada seseorang, maka resiko untuk terpapar virus covid 19 akan semakin rendah, karena virus ini dapat ditularkan dari manusia ke manusia yang lainnya. Tetapi jika sistem kekebalan tubuh kita melemah maka kemampuan untuk melindungi tubuh juga berkurang sehingga virus covid 19 dapat menjangkiti tumbuh dan berkembang dalam tubuh. Struktur genom virus ini memiliki pola seperti coronavirus pada umumnya. Sekuens SARSCoV-2 memiliki kemiripan dengan corona virus yang diisolasi pada kelelawar, sehingga muncul hipotesis bahwa SARS-CoV-2 berasal dari kelelawar yang kemudian bermutasi dan menginfeksi manusia (Zhou et al, 2020).

WHO semenjak Januari 2020 telah menyatakan dunia masuk ke dalam darurat global terkait virus ini (Sebayang, 2020). COVID-19 pertama dilaporkan di Indonesia pada tanggal 2 Maret 2020 sejumlah dua kasus. Hingga saat ini grafik peningkatan pasien covid 19 di Indonesia masih menunjukkan tren naik turun hingga mencapai 81.668 ribu pasien positif. Berdasarkan pembahasan latar belakang tersebut maka pelaksana melakukan sosialisasi peningkatan kebugaran jasmani dengan tujuan untuk menjaga stabilitas imun tubuh guna mencegah penularan virus covid 19 di desa Sumberberas Kecamatan Muncar. Alasan utama pelaksana mengangkat topik sosialisasi tersebut adalah dikarenakan kurangnya kesadaran para masyarakat di daerah tersebut untuk melakukan aktivitas fisik.

\section{Metode}

Pada kegiatan pengabdian masyarakat ini dilakukan dengan menggunakan metode partisipatif, yaitu pendekatan yang berorientasi kepada upaya peningkatan peran serta masyarakat secara langsung dalam berbagai proses dan pelaksanaan.

\section{Khalayak Sasaran}

Sasaran kegiatan pengabdian ini adalah masyarakat di Desa Sumberberas lingkungan RW 04 yang berperan sebagai peserta kegiatan sosialisasi.

\section{Tahapan Persiapan}

Tahapan persiapan meliputi survei lokasi, setelah itu berkoordinasi dengan pihak RW untuk melakukan izin terkait pelaksanaan kegiatan sosialisasi yang bertempat di halaman masjid Al Munir desa Sumberberas dan tentunya juga dengan memperhatikan protokol kesehatan dan physical 
distancing. Selain itu kami melakukan sosialisasi terhadap masyarakat terkait pentingnya kegiatan ini di masa pandemi covid 19.

Menyediakan sarana prasarana yang mendukung berlangsungnya kegiatan pengabdian ini dan kebutuhan konsumsi.

3. Tahapan Pelaksanaan

a. Tahap pelaksanaan dilakukan selama 2 hari, yaitu pada tanggal 18-19 Mei 2020, pada pukul 09.00- 12.00 wib.

b. Peserta sosialisasi mengisi absensi dan biodata.

C. Peserta mengikuti prosedur protokol kesehatan

d. Peserta menggunakan tempat yang telah disediakan oleh pelaksana dan RW.

4. Tahap Evaluasi Akhir

Pada tahap ini dilakukan pembuatan laporan tahap akhir, yang berisi laporan dari hasil kegiatan sosialisasi dan kritik yang berkaitan dengan pelaksanaan program.

\section{Hasil dan Diskusi}

Kegiatan sosialisasi peningkatan kebugaran jasmani ini dimulai tanggal 18-19 Juli 2020, pukul 09.00- 12.00 wib dan berlokasi di halaman masjid Al Munir desa Sumberberas. Pelaksanaan awal peserta sosialisasi mengisi absen terlebih dahulu, kemudian peserta menggunakan tempat yang telah disediakan oleh pelaksana dan RW. Pelaksanaan sosialisasi diberikan oleh tim pelaksana pengabdian masyarakat dengan menggunakan laptop, LCD dan michrophone serta materi yang dibagikan ke peserta. Materi terkait aktivitas fisik yang disampaikan dan direkomendasikan adalah jogging, bersepeda dan senam aerobik dengan memperhatikan protokol kesehatan dan physical distancing. Terlihat antusiasme para peserta yang cukup baik, yaitu dengan munculnya beberapa pertanyaan ketika dalam sesi diskusi.

Penyampaian materi sosialisasi di hari pertama adalah pemahaman dasar keterkaitan kondisi fisik dan kebugaran jasmani terhadap sistem imun tubuh manusia. Kemudian pemahaman seperti apa bahaya dan dampak dari virus covid 19 serta cara cara penularan dari virus tersebut. untuk hari kedua adalah materi terkait macam-macam olahraga ringan dan ekonomis yang dapat menjaga kondisi fisik serta meningkatkan kebugaran jasmani seseorang dengan tujuan untuk meningkatkan daya tahan atau sistem imun tubuh.

Di hari pertama dalam pelaksanaan kegiatan sosialisasi ini terdapat 30 peserta yang berpartisipasi 
GANDRUNG: Jurnal Pengabdian Kepada Masyarakat ISSN: 2721-6136 (Online)

dan di hari kedua terdapat penambahan anggota yaitu sebanyak 20 orang. Sehingga total peserta kegiatan sosialisasi ini adalah sebanyak 50 orang. Berdasarkan dari hasil wawancara, di dapatkan fakta bahwa para peserta ini di dominasi oleh kalangan masyarakat dari tingkat strata pendidikan dan perekonomian yang cukup rendah. Sehingga dengan adanya kegiatan sosialisasi ini, masyarakat merasa terfasilitasi dan terbantu atas ketidakpahaman dari pengetahuan mereka untuk meningkatkan kebugaran jasmani dan jenis olahraga apa yang harus dilakukan.

Berdasarkan dari hasil tersebut maka dapat disimpulkan bahwa partisipasi para masyarakat yang mengikuti kegiatan sosialisasi ini tergolong baik dan masyarakat juga bersikap sangat antusias. Berikut pelaksana cantumkan dokumentasi dari kegiatan pengabdian masyarakat sebagai berikut:
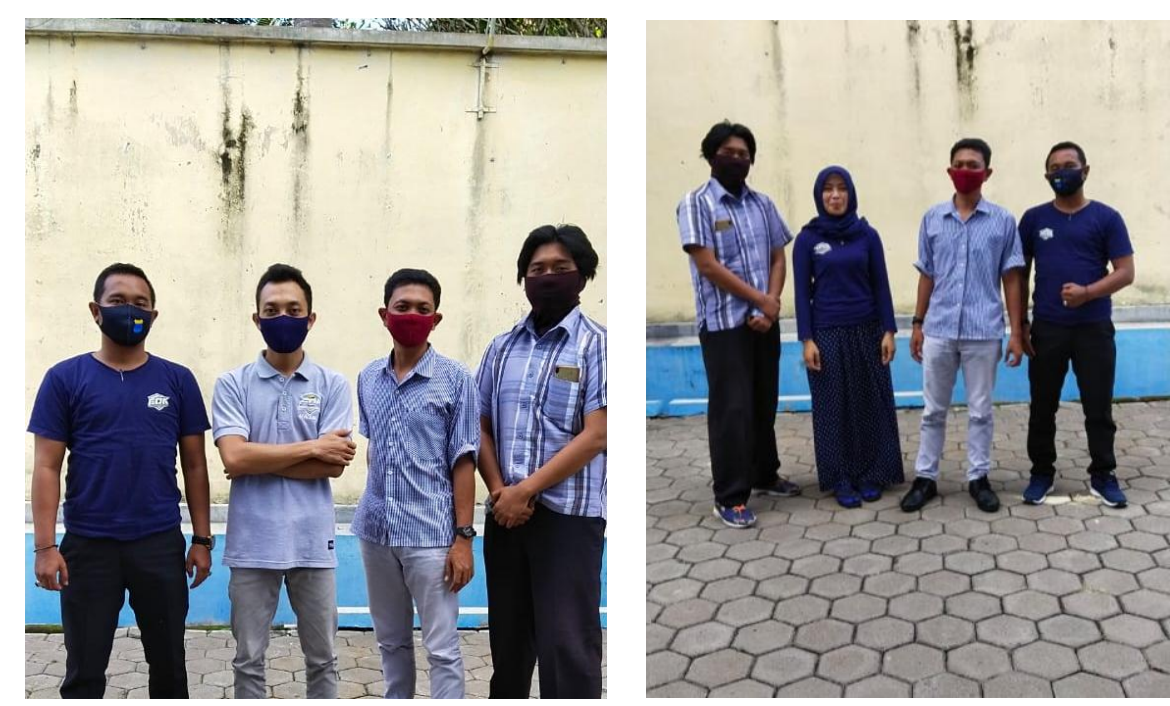

Gambar 1. Kegiatan Sosialisasi Peningkatan Kebugaran Jasmani

\section{Kesimpulan}

Berdasarkan hasil evaluasi dari pelaksanaan sosialisasi peningkatan kebugaran jasmani di era pandemi covid 19 ini, masyarakat merasa senang dan terbantu atas pemberian pemahaman terkait cara meningkatkan kebugaran jasmani dengan menggunakan beberapa macam jenis-jenis olahraga yang diberikan. Awalnya beberapa masyarakat tidak memahami bahwasanya aktifitas fisik atau kegiatan berolahraga dapat meningkatkan sistem daya tahan tubuh (imunitas) seseorang, yang berpotensi dapat mecegah paparan dari beberapa penyakit yang disebabkan oleh virus, salah satunya covid 19.

\section{Daftar Referensi}

Sebayang, R. (2020, Januari 31). Awas! WHO Akhirnya Tetapkan Corona Darurat Global. CNBC Indonesia. Diunduh dari https://www.cnbcindonesia.com/news/20200131060856-4- 
GANDRUNG: Jurnal Pengabdian Kepada Masyarakat ISSN: 2721-6136 (Online)

134146/awas-whoakhirnya-tetapkan-corona-darurat-global

Siswanto, dkk (2013). Peran Beberapa Zat Gizi Mikro Dalam Sistem Imunitas. Gizi Indon. 36 (1): 57-64.

Sukamti, E, R., dkk (2016). Profil Kebugaran Jasmani Dan Status Kesehatan Instruktur Senam Aerobik Di Yogyakarta. Jurnal Olahraga Prestasi. 12 (2): 31-40

Zhou P, Yang X-L, Wang X-G, Hu B, Zhang L, Zhang W, et al (2020). A pneumonia outbreak associated with a new coronavirus of probable bat origin. Nature. 579(7798):270-3 